NBER WORKING PAPER SERIES

\title{
THE CONCEPT OF SYSTEMATIC CORRUPTION IN AMERICAN POLITICAL AND ECONOMIC HISTORY
}

\author{
John Joseph Wallis \\ Working Paper 10952 \\ http://www.nber.org/papers/w10952 \\ NATIONAL BUREAU OF ECONOMIC RESEARCH \\ 1050 Massachusetts Avenue \\ Cambridge, MA 02138 \\ December 2004
}

Forthcoming in Corruption and Reform, edited by Claudia Goldin and Ed Glaeser. This paper originated in a series of conversations with Claudia Goldin, who I gratefully acknowledge. Without her support and encouragement it never would have been written. Ed Glaeser challenged me to extend the paper farther back in time, a license I took advantage of. Conversations with Naomi Lamoreaux, Lee Alston, and William Novak as well as the discussion of Morton Keller at the first pre-conference, while not specifically on the topic of this paper, were nonetheless extremely helpful, as were Professor Keller's comments at the final conference. My graduate class in American Economic History Spring 2004 endured a great deal of talk about corruption and I thank them for their patience. At a critical time, Jeff Smith, Sally Snyder, and Barbara Gill forced me to be more precise about the concept of systematic corruption. The seminar in Early American History at the University of Maryland gave me a valuable opportunity to present the paper to historians and their comments were very valuable. Finally, the central idea in the paper developed in conjunction with my ongoing conversations with Barry Weingast and Doug North. The views expressed herein are those of the author(s) and do not necessarily reflect the views of the National Bureau of Economic Research.

(C) 2004 by John Joseph Wallis. All rights reserved. Short sections of text, not to exceed two paragraphs, may be quoted without explicit permission provided that full credit, including $\odot$ notice, is given to the source. 
The Concept of Systematic Corruption in American Political and Economic History

John Joseph Wallis

NBER Working Paper No. 10952

December 2004

JEL No. B1, N0, N2, N4, H0, H1

\begin{abstract}
$\underline{\text { ABSTRACT }}$
The critical role of governance in the promotion of economic development has created intense interest in the manner in which the United States eliminated corruption. This paper examines the concept of corruption in American history; tracing the term corruption to its roots in British political philosophy of the 17th and 18th century, and from there back to Machiavelli, Polybius and Artistole. Corruption was defined prior to 1850 in a way that was significantly different from how it was defined in the Progressive Era. "Systematic corruption" embodied the idea that political actors manipulated the economic system to create economic rents that politicians could use to secure control of the government. In other words, politics corrupts economics. The classic cure for systematic corruption was balanced government. Americans fought for independence because they believed that the British government was corrupt. The structure of American constitutions was shaped by the need to implement balanced government. Conflict and debate over the implementation of balanced government dominated the political agenda until the 1840s, when states began moving regulatory policy firmly towards open entry and free competition. By the 1890s, systematic corruption had essentially appeared from political discourse. By then corruption had come to take on its modern meaning: the idea that economic interests corrupt the political process. What modern developing countries with corrupt governments need to learn is how the United States eliminated systematic corruption.

John Joseph Wallis Department of Economics University of Maryland College Park, MD 20742 and NBER wallis@econ.umd.edu
\end{abstract}


What is really educational and beneficial to students of history is the clear view of the causes of events, and the consequent power of choosing the better policy in a particular case. Now in every practical undertaking by a state we must regard as the most powerful agent for success or failure the form of its constitution; for from this as from a fountainhead all conceptions and plans of action not only proceed, but attain their consummation. -- The Histories of Polybius, Book VI.

Corruption is a pervasive concept in western political thought. Corruption played a central role in the political philosophies of Aristotle, Polybius, Machaivelli and the $16^{\text {th }}$ century Italians, and Harrington and the $17^{\text {th }}$ and $18^{\text {th }}$ century English writers who became known as Whigs or Commonwealthmen. The Whig indictment of corruption in British government shaped American colonial political thought and prepared the colonists to interpret the actions of Crown and Parliament after 1763 as unconstitutional threats to their fundamental liberties as British citizens. Once independent, Americans worried continuously about their governments and how to design their political institutions to limit corruption. ${ }^{1}$ The reawakening of interest among economists in the role played by political institutions as a determinant of economic performance has stimulated a renewed interest in the quality of governance: of corruption. While corruption did not disappear from $20^{\text {th }}$ century American politics, it has ceased to be major concern. The self-conscious, centuries long debate over corruption in western political thought in general, and in American politics in particular, suggests that a longer view of American history might offer insights into how economic and political institutions can curb corruption.

The original idea behind the conference on "Corruption and Reform" was to examine the Progressive era, but it was clear that Americans had been grappling with corruption long before the $1890 \mathrm{~s}$. As it turns out, Progressive era reformers and $21^{\text {th }}$ century economists think about corruption in a way that is, in a critical dimension, 180 degrees removed from the concept of 
corruption that prevailed until the mid-nineteenth century. The title of McCormack's essay "The Discovery that Business Corrupts Politics" captures the essence of the modern concept of corruption. Economic interests corrupt politicians and bureaucrats by offering them options to promote their own interests at the expense of the public good, or as Shleifer and Vishny define corruption "as the sale by government officials of government property for personal gain." 2 The fear that economic interests might capture or influence government policy is the essence of modern corruption. In contrast, eighteenth century British - English, Scotch, Irish, and American - political thinkers worried much more that political interests would coopt economic groups to fundamentally erode the integrity of basic political rights and liberties. They feared that a group of government officials -- the king and his evil ministers, for example -- could use the grant of economic privileges to secure political support for a takeover of the government.

The terms systematic and venal corruption are used to identify earlier and later definitions of corruption. Systematic corruption is an idea. It is also a concrete form of political behavior. In polities plagued with systematic corruption, political agents deliberately create economic rents through selectively granting economic privileges. These rents bind the interests of the recipients to the politicians who create the rents. The politicians manipulate the interests they create - a party, faction, or conspiracy - to control the government. Systematic corruption uses the economic rents generated by limited entry and economic privileges to control the political system. Political interests corrupt the economic system for political gains: politics corrupts economics. In contrast, venal corruption denotes the modern concept of corruption: the pursuit of private economic interests through the political process. Venal corruption occurs when economics corrupts politics. In terms of social welfare and economic growth, venal 
corruption is small potatoes compared to systematic corruption. Polities with systematically corrupt governments are fundamentally unable to promote economic development. These are not rent seeking governments, they are rent creating governments. The very existence of a systematically corrupt government depends on limiting access to markets and resources, to create rents that bind the interests of the ruling coalition together. It appears that many developing countries of the world today suffer from systematic corruption.

If the history of the United States is to provide lessons for modern developing countries, it is critically important that we understand what kind of corruption we are talking about. "Corruption" is an anachronism: a word that means something different today than it did two centuries ago. In the late $18^{\text {th }}$ and early $19^{\text {th }}$ centuries Americans were fixated on corruption as the nation's primary political problem. They feared systematic corruption, not venal corruption. When Americans wrote their first constitutions, and later replaced and amended them, they consciously tried to limit systematic corruption. Often they explained their actions in a way that appears, to modern readers, to reflect paranoia over corruption. A deeper understanding of American intellectual history is required to understand their legitimate fears. Americans were not afraid that their governments actually were systematically corrupt, indeed their governments were not corrupt by the standards of many of today's developing countries. Instead they worried that if they were not vigilant in protecting their liberties today that their government would become corrupt and quickly evolve into a tyranny tomorrow. They worried about what was going to happen next.

The paper follows development the concept of systematic corruption from Aristotle and Polybius, Machiavelli and Harrington, up through the $18^{\text {th }}$ century British Whigs, Americans in 
the Revolution, in the 1790s, the 1830s, and finally the Progressive Era. The paper's fundamental conclusion is that the most basic economic institution in a modern thriving developed economy - unlimited free entry and competition unrestricted by governments developed as a solution to systematic corruption: a solution to the political problem of constraining narrow political groups from obtaining uncontested control of governments. Open markets with free competition did not develop historically as a way to produce economic growth and enhance the wealth of nations; open markets were an economic tool used by political groups to eliminate systematic corruption. Eliminating systematic corruption required an economic solution to a political problem. By the 1890s and the Progressive movement, the danger of systematic corruption had passed from the American political conscious. Progressive reformers, as the essays in this book document, were concerned about containing venal corruption. The real lesson developing countries ca learn from American history is how the United States eliminated systematic corruption, not how twentieth century America manages venal corruption.

Three elements appear repeatedly throughout this history. First, systematic corruption threatened rights and liberties and was believed to lead directly to tyranny and slavery. Systematic corruption was an infra-marginal concept: the very existence of civil society was at stake. What seems to modern ears to be overblown rhetoric - the threat of tyranny and slavery -was, in fact, precisely what the best educated and most knowledgeable people feared would happen if systematic corruption went unchecked. ${ }^{3}$ Second, by the late $17^{\text {th }}$ century, corruption was always viewed in constitutional terms. Corruption violated some aspect of the constitutional arrangement. As a result, the cures for corruption were constitutional. Americans responded repeatedly to the threat of corruption by redesigning political and economic institutions at the 
constitutional level. The result of this continual tinkering is America's contribution to the major political accomplishment of modern western economies: the concept of limited, constitutional government. Finally, the mechanism by which political groups exercise corrupt influences on the polity are, from 1700 onwards, always portrayed as economic mechanisms. Political manipulation of economic interests involved in the growing government debt, the financial management of the debt, and the supply of the Army and Navy through private contractors fueled fears of corruption in Britain. In the United States, political manipulation of efforts to promote economic development by chartering private business corporations focused political concerns about corruption and the consequences of majority rule in a democratic republic. Since systematic corruption was based on the rents created by limited entry, the creation of privileged corporations was always a warning sign of potential corruption. By the 1840 s, the United States had established the general principle that entry into all lines of business should be open to all entrants (free incorporation), markets should be open to unlimited entry, and competition between firms should be generally unregulated. These fundamental institutions of modern developed economies developed in the early $19^{\text {th }}$ century United States as the solution to a political problem, not an economic problem. This paper traces how that happened.

\section{$* *$}

The King's ministers were not attacked for sitting in Parliament, but they were attacked for allegedly filling Parliament with the recipients of government patronage. For what was universally acknowledged was that if the members of the legislatures became dependent on patronage, the legislature would cease to be independent and the balance of the constitution would become corrupt. Corruption on an eighteenth-century tongue where it was an exceedingly common term - meant not only venality, but disturbance of the political conditions necessary to human virtue and freedom.

— J.G.A. Pocock $(1985, \text { p. } 78)^{4}$

The concept of mixed or balanced government can be traced back through western 
political philosophy to Aristotle. Corruption was closely tied to the idea of constitutional balance and the changing distribution of power within governments. The nature of both balanced government and corruption evolved together until, by 1780 , corruption became synonymous with a failure to maintain balance in the constitutional structure of government.

Aristotle defined pure forms of government as those that "govern with a view to the common interest." The pure and corrupt forms "are as follows: - of kingship, tyranny; of aristocracy, oligarchy; and of constitutional government, democracy." (1996, Book III, $1279^{\text {a3}} 30$ and $1279^{\mathrm{b}} 4$ ). Aristotle's task in the Politics was to understand how constitutions affected the behavior of governments, with the purpose of discerning how good governments might be instituted in human society. ${ }^{5}$ To classic thinkers there was a profound difference between corruption of the individual and the political system. The concept of systematic corruption mattered so much because it was intimately tied to the concept of a constitution. Constitutions were originally thought of as literally the body politic, not as written documents or theoretical constructs. ${ }^{6}$ All physical bodies exhibit a cycle of growth, maturity, and decay: corruption. Corruption happened to constitutions, just as certainly decay and death happened to individuals. The central question of political philosophy asked whether a political constitution could possibly be devised that did not inevitably end in corruption.

Polybius developed Aristotle's categories of pure and corrupt forms of government into an explicit cyclical theory of constitutional development:

So then we enumerate six forms of government, -- the three commonly spoken of which I have just mentioned, [the pure forms of kingship, aristocracy, and democracy] and three more allied forms, I mean despotism, oligarchy and mob-rule. The first of these arises without artificial aid and in the natural order of events. Next to this, and produced from it by the aid of art and adjustment, comes kingship; which degenerating into the evil form allied to it, by which I mean tyranny, both are once more destroyed and aristocracy 
produced. Again the latter being in the course of nature perverted to oligarchy, and the people passionately avenging the unjust acts of their rulers, democracy comes into existence; which again by its violence and contempt of law becomes sheer mob-rule. No clearer proof of the truth of what I say could be obtained than by a careful observation of the natural origin, genesis, and decadence of these several forms of government. For it is only by seeing distinctly how each of them is produced that a distinct view can also be obtained of its growth, zenith, and decadence, and the time, circumstance, and place in which each of these may be expected to recur. (Polybius, 1962, Book 6, 4, p. 460)

Polybius developed a theory of "the regular cycle of constitutional revolutions, in which and the natural order in which constitutions change, are transformed, and return again to their original stage." (Book 6, 10, p. 466) Any society with governments of the pure forms, inevitably cycled from kingship, through tyranny, aristocracy, oligarchy, democracy, and mob-rule. The mob being subdued by the noble and pure king, setting the cycle in motion again. For Polybius, corruption was explicitly systematic. It was the process by which one form of government evolved into another form. It was a force beyond the individual, an "undeviating law of nature" in unmixed governments.

Polybius also believed that it was possible to prevent corruption by resort to mixed and balanced governments that combined elements of all three pure types, which he saw in the historical example of Lycurgus who:

accordingly combined together all the excellences and distinctive features of the best constitutions, that no part should become unduly predominant, and be perverted into its kindred vice; and that, each power being checked by the others, no one part should turn the scale or decisively out balance the others; but that, by being accurately adjusted and in exact equilibrium, the whole might remain long steady like a ship sailing close to the wind. The royal power was prevented from growing insolent by fear of the people, which had also assigned to it an adequate share in the constitution. The people in their turn were restrained from a bold contempt of the kings by fear of the Gerusia: the members of which, being selected on grounds of merit, were certain to throw their influence on the side of justice in every question that arose; and thus the party placed at a disadvantage by its conservative tendency was always strengthened and supported by the weight and influence of the Gerusia. The result of this combination has been that the Lacedaemonians retained their freedom for the longest period of any people with which 
we are acquainted. (Book 6, 10, p. 466-7)

Machiavelli took up Polybius. Machiavelli was concerned with stability and the process of political change. ${ }^{7}$ Anything that disrupted the balance of the constitution was "technically" corruption, whether it resulted from morally corrupt individual behavior or not. Systematic corruption occurred because of inherent tendencies in the structure of societies.

The very term balance suggests the modern concept of an equilibrium, but constitutional balance was not thought to be a stable or self-enforcing equilibrium. Small changes in the relative balance of power between the groups that made up the political and social order could disrupt the system. A balanced constitution could ward off corruption, but it had to be maintained by the eternal vigilance of fallible human care and attention. Maintaining the balance required politicians and philosophers to define exactly what constituted the balance, that is to define exactly what behavior was "unconstitutional" or corrupt. This way of thinking produced two important consequences:

First, articulating the concept of systematic corruption was fundamental to the evolution of constitutions as fundamental law, captured in a written document, and realized in the lives of men and women through custom, practice, conflict, and adjudication. Implementing the idea that societies should be governed by laws, not men, required that society at large agree on a way to identify when a society was corrupted.

Second, the balanced constitution was a theoretical construct similar to a unique and universal maximum. ${ }^{8}$ Any movement away from the balance was a movement toward tyranny and slavery. This was true whether the movement was towards tyranny of the one, the many, or the few. The balanced constitution was a perfect equipoise from which a slippery slope led 
downwards in all directions. Any change in the balance was inherently corrupt. Systematic corruption was not about specific behaviors, it was not like moral and ethical corruption. It was change that destabilized the political order.

The ascension of James I in 1603 initiated a century of Stuart rule in England. Just before the civil war between the Stuarts and Parliament began, the conflict produced a defining moment in the history of the English constitution. On June 21, 1642, two of Charles I advisors drafted and persuaded the king to issue a document, His Majesty's Answer to the Nineteen Propositions of Both Houses of Parliament, in which the king declared that England was a mixed government and not a condescending monarchy. ${ }^{9}$ The Answer was a critical turning point in constitutional history because in it the king admitted that England possessed a balanced government, not an absolute monarchy. It was an admission that royalists immediately began pressing the king to retract. But the Answer quickly became part of the English constitutional canon. ${ }^{10}$ The Answer did not concede sovereignty to Parliament nor was it a concession of royal prerogatives. It cemented the constitutionality of the monarchy and enshrined the idea of balanced government.

But if the Answer guaranteed a balanced constitution, it did very little to indicate exactly how the balance was to be defined, maintained, and allowed to change. During the Interregnum, the writings of James Harrington helped define the constitutional balance and move it from a static to a dynamic basis. Harrington made two fundamental contributions. First, to delineate how the distribution of military power in a society was a function of the distribution of land tenure, and thus how every government rested on a particular set of property rights in land. Second, to show how the constitutional balance within government must correspond to the balance of military power between social orders implied by the distribution of land tenure. 
Harrington's model contained two balances, of government and military power. His genius was to see that these two balances must correspond. A constitutional system that gave more power to an element of society (king, aristocracy, the people) than the relevant share of land possessed by that element of the population was inevitably unstable. Either the constitution or the underlying balance of military power must change and, in classic Polybian terms, Harrington defined corruption as change: "corruption in this sense signifieth no more than that the corruption of one government (as in natural bodies) is the generation of another..." (1992, p. 60-61). Harrington saw balanced government as a way to provide political stability and prevent the endless struggles of the one, the few, and the many to control the government and the warfare, disruption, and occasional tyranny that ensued.

After the restoration of Charles II in 1660, the Stuarts continued to press the royal prerogative. ${ }^{11}$ The Answers and Harrington's Oceana defined a constitutional balance, but it was not yet in place. Conflict between King and Parliaments resulted in the deposition of James and the installation of William and Mary. Between 1660 and 1688, "commonwealthmen" or "True Whigs" or "Real Whigs" articulated a version of the balanced constitution and its associated corruptions. ${ }^{12}$ By 1675 , they had developed a coherent position containing the basic themes of opposition ideology, destined to be repeated for the next century. ${ }^{13}$ Balanced government required independent actors in king, lords and commons. The creation of a standing army, as opposed to a militia, was the starting point of their critique of Stuart government. ${ }^{14} \mathrm{~A}$ professional standing army threatened the independence of Parliament by filling the Commons with professional soldiers and other office holders who careers and livelihood depended on the good will and patronage of the executive. "The standing army appears in this context as an 
instrument of corruption rather than of dictatorship. Army officers in Parliament are placemen, and they encourage the growth of a military establishment outside parliamentary control...” (Pocock, 1973 p. 125).

The Glorious Revolution of 1688 and the new arrangements between King William and Parliament produced a complementary set of institutional changes in fiscal policy and government administration. They included the Bank of England, professionalization of tax collection and administration, and the development of new methods to fund the growing national debt. ${ }^{15}$ This lowered the cost of government borrowing and gave Britain an important edge in the wars with France. Continuous warfare created a military-industrial complex in England. Between 1700 and 1800 government expenditures rose from 5 percent of income to 20 percent of income. ${ }^{16}$ This unprecedented expansion of state power was equally the accomplishment of Parliament and the King, for Parliament controlled tax policy.

It was in the early $18^{\text {th }}$ century that systematic corruption began to take on an explicitly economic character. The British came through the civil wars of the $17^{\text {th }}$ century with their belief in a balanced constitution intact and enhanced. They increasingly saw the House of Lords as a balance between a competing Monarchy and the House of Commons. ${ }^{17}$ Independence of the three parts was required to maintain the balance. Whigs directed their complaints at the mechanisms by which the crown exerted influence in the Commons and subverted parliamentary independence. These were parliamentary patronage, the public credit, and political parties. If the King obtained enough influence in Parliament to suborn its independence, liberty would be lost and tyranny and slavery would follow. ${ }^{18}$

As government expenditures rose the executive had a growing number of patronage 
positions at its disposal in the Army, Navy, Treasury, Customs, and Excise. By the time of the American Revolution, close to half of the House of Commons were placemen, pensioners, or represented electoral districts under control of the King and his ministers. ${ }^{19}$ The steadily growing public debt created a class creditors with a direct interest in the financial stability of the government, many of them members of Parliament. The large profits to be made in marketing and servicing the debt went to the favored few financial houses, banks, and chartered trading companies all of whom had connections in both the executive and Parliament. There was ample reason to doubt the independence of individual members of Parliament. And finally, the manipulations of politicians like Walpole created groups within the government whose interest "is that of men attached to the government; or to speak more properly, to the persons of those who govern; or, to speak more properly still, to the power profit, or protection they acquire by the favour of these persons, but enemies to the constitution." (Bolingbroke, 1992, p. 85). The creation of a political party within Parliament headed by the King, organized by his ministers, financed by corporate privileges, and coordinated by the national debt, threatened the end of balanced government and the establishment of a unitary, executive tyranny. ${ }^{20}$

The British in the early $18^{\text {th }}$ century certainly enjoyed better government than they, and perhaps the world, had ever seen. Britons on both sides of the Atlantic extolled the virtues of the British constitution. John Toland called the British government "the most free and best constituted in the world." John Adams claimed "No Government that ever existed was so essentially free." Even the Frenchman Montesquieu talked of "this beautiful system."21 The Whigs believed in the perfect balance of the British constitution. In this light, it is easy to dismiss Whig claims of corruption as paranoia. To do so, however, overlooks that Whigs were 
not concerned about the current state of Britain. Whigs feared what would happen next. They had no historical yardstick to judge whether the change that British society and government was undergoing in the $18^{\text {th }}$ century was good or bad. Commonwealthmen believed, with the deepest conviction, that if executive influence in Parliament was allowed to go unchecked, then the next stage in British government would inevitably be tyranny and slavery.

So the Whigs criticized the government's relation to the economy. Adam Smith attacked the system of government granted mercantilist privileges. In Cato's Letters, Trenchard and Gordon challenged the use of chartered corporations to promote economic activity potentially created economic rents (by limiting entry) that could be used by the Crown to cement economic interests to his cause. ${ }^{22}$ "For as to that class of ravens, whose wealth has cost the nation its all, as they are manifest enemies to God and man, no man can call them his neighbours: They are rogues of prey, they are stock-jobbers, they are a conspiracy of stock-jobbers!"23 The "financial revolution" brought with it numerous instances of special privileges granted by the government. ${ }^{24}$ The combined charges of systematic corruption, suborning the independence of politicians and Parliament, and individual corruption, the venality and greed of stock-jobbers and speculators, packed a powerful message.

By mid-18th century commonwealthmen decried the corrupting evils of executive patronage, the public credit, and parties. Commonwealth ideals were important elements of the political conversation in the $18^{\text {th }}$ century; the term "conscience Whigs" conveys the main contribution of commonwealth thought. They defined, with clear bright lines, what was and was not constitutional. Britain, of course, was in the midst of a phenomenal rise to world power and most Britons were happily apathetic about the supposed corruption of their government. In 
Briton, the commonwealthmen "were not in any sense of the word an organized opposition...Without leaders and organization the reformers failed. When they achieved these they still failed to attract sufficient public support and interest. A part of their failure must be attributed to their detestation of party... The Real Whigs were not a coherent party. The professed almost as many creeds in politics as in religion." Yet, "In America the academic ideas of the Whigs of the British Isles were fruitful and found practical expression.. ${ }^{25}$
$* * *$
Sir, we have done everything that could be done to avert the storm which is now coming on. We have petitioned; we have remonstrated; we have supplicated; we have prostrated ourselves before the throne, and have implored its interposition to arrest the tyrannical hands of the ministry and Parliament.
The battle, sir, is not to the strong alone; it is to the vigilant, the active, the brave. Besides, sir, we have no election. If we were base enough to desire it, it is now too late to retire from the contest. There is no retreat but in submission and slavery! Our chains are forged. Their clanking may be heard on the plains of Boston! The war is inevitable -- and let it come!
- Patrick Henry, Address to the Virginia Provincial Convention, March 23,1775.

The notion of a legislative power exercised conjointly by kings, lords and commons is a notion of legislative sovereignty undeveloped in classical republican theory; its presence in the Answer is a reminder that the notion of 'separation of powers', though invented largely in England, could not be effective there and could be realized in the United States only after rejection of parliamentary government.

-J.G.A. Pocock, 1987, p. 310.

We have reached the point where British and American paths divide. The "republican synthesis" in American history provides a convincing explanation for why Americans revolted and what "made their revolution so unusual, for they revolted not against the English constitution but on behalf of it." ${ }^{26}$ The desire to preserve the existing constitution made the American revolution one motivated by fear rather than hope. The widespread perception of English corruption, on both sides of the Atlantic, inexorably drove the Americans to 
independence once a wedge opened between Parliament and the colonies in 1763. The fear in the American colonies was that England "once the land of liberty -- the school of patriots -- the nurse of heroes, has become the land of slavery -- the school of parricides and the nurse of tyrants. ${ }^{27}$ At its root, the fear driving the American revolution was Polybian. The influence of the executive in Parliament had unbalanced the constitution. What inevitably followed monarchy, no matter how pure the intentions of those who produced the monarchy, was tyranny. As Patrick Henry declared: "Our chains are forged. Their clanking may be heard on the plains of Boston!”

Any government organized along commonwealth lines should immediately have put in place a constitution with balanced government. In May of 1776, the Continental Congress asked the states to write their own constitutions. By July 3, New Jersey had drafted a new constitution which, among its many features, distinctly articulated the separation of powers:

$\mathrm{XX}$. That the legislative department of this government may, as much as possible, be, preserved from all suspicion of corruption, none of the Judges of the Supreme or other Courts, Sheriffs, or any other person or persons possessed of any post of profit under the government, other than Justices of the Peace, shall be entitled to a seat in the Assembly: but that, on his being elected, and taking his seat, his office or post shall be considered as vacant. ${ }^{28}$

The Constitution of Maryland ratified in November, stipulated in Section 6 of the Declaration of Rights: "That the legislative, executive and judicial powers of government, ought to be forever separate and distinct from each other." Separation of powers was the most visible way that Americans addressed systematic political corruption, but the entire structure of early state constitutions with their articulated branches, attempted to systematize balanced government.

The powers assumed by the states in their constitutions were not powers necessarily denied to the national government. But once states defined their powers they could not be taken 
by the national government without substantial political cost. The second national constitution, written in 1787, gave the national government broad and generous powers. But only in the areas of military and international affairs, public lands, international trade and commercial policy, and (to a lesser and immediately disputed extent) financial and monetary policy, did the national government possess well defined exclusive powers. Even in these areas, with the exception of military defense and international relations, the national government subsequently found it extremely difficult for political reasons to exercise its constitutional powers. ${ }^{29}$ National government action inevitably raised the specter of corruption.

The ability of states to legislate, regulate, or promote almost any aspect of economic and social behavior meant that states, and not the national government, became the focal point of economic policies. Americans were embarking on two new experiments in government: written constitutions and widespread government support of private organizations. The first experiment is a central part of American history. The second experiment, successful as it was, is so taken for granted that we rarely recognize how important government support of private organizations was for American social and economic development. As de Toqueville famously noted: "Americans of all ages, all stations in life, and all types of dispositions are forever forming associations. There are not only commercial and industrial associations in which all take part, but others of a thousand different types - religious, moral, serious, futile, very general and very limited, immensely large and very minute... In every case, at the head of any new undertaking, where in France you would find the government or in England some territorial magnate, in the United States you are sure to find an association.” (1966, p. 513)

The American colonists brought the ancient English constitution with them, but not a king or an aristocracy, two of the critical elements in the constitutional balance. This led to a 
more egalitarian society, a deep belief in the right of individuals to assemble, and more vigorous private sector organizations. In Europe, the right to form voluntary organizations was not a universal right; and one found governments and territorial magnates at the head of organizations because they possessed the sometimes implicit, but often explicit ability to form organizations. The ability to form corporations was limited to the social and economic elite. Limited entry created the economic rents that made royal grants of privilege to the monied interest so valuable. In America, freedom to assemble, the ability to form religious, political, economic, and social organization did not go undisputed after the revolution. Deciding how much public support should be given to private organization was important and, at least in the economic and political world, very contentious.

America's balanced state constitutions recognized the Harringtonian imperative of balancing power within the government in the same proportion as land ownership was balanced in the population. "Power results from the real property of society." 30 The equality of land ownership posed new and vexing problems for American politicians, problems without English antecedents. The distribution of land did not mirror the distribution of social prestige or the presumed distribution of leadership talents within the "natural elite." Freedom of assembly, freedom of speech, and freedom of petition were fundamental rights. How far did these rights extend into the politically competent, independent, land owning citizenry? Who had the right to vote, to incorporate a business, or form a political party? Britain's financial revolution did not represent a move toward an economy or society with more open entry; it restricted entry. Smith and the classical economists built their criticism of government policy on mercantilist limitations on access to economic organization. Kings and ministers used limited access to created economic rents, then used the spoils from the rents to purchase political influence, and thus 
eroded the independence of Parliament and corrupted the entire political system. Corporations and stock-jobbers represented the very essence of systematic and venal corruption. How was the United States to deal with the identical problem?

\section{$* * * *$}

"It is hard to imagine how by deliberate intent, Alexander Hamilton's economic program for the new republic could have been better calculated to exacerbate these [commonwealth] fears... they inevitably brought to mind the entire system of eighteenthcentury English governmental finance, with all the consequences that entailed for minds shaped by British opposition thought."

— Lance Banning, 1978, p. 128

Straightening out the nation's finances instigated the first battle over corruption in the new republic. Hamilton's proposed financial policies - refunding national and state debts, a national bank, a moderate revenue tariff, and excise taxes - all stimulated opposition and debate when Congress considered them in the first Congress, which ended in March of 1791. Each of Hamilton's measures raised fears of corruption in classic commonwealth terms, but all of them passed. The debate that ensued in the summer of 1791 over what the new financial system meant, however, produced a conflagration of fears over corruption and led to the creation of an opposition party in the United States. All of the policy measures at issue were economic. The important element in the debate, however, was the effect of the economic policies on politics.

We have already seen how the financial revolution in England created a funded national debt, a bureaucracy of excise and tariff collectors, a national bank, and an interlocking set of financial intermediaries and chartered corporations that marketed and traded in government debt. As the bureaucracy expanded, so did opportunities for executive patronage. The ability to tie the interests of the financial community to the policies of the government through the medium of the national debt and corporate charters allowed the Crown to extend its influence and undermine the independence of Parliament. Although stock jobbers and financial parvenus were reviled for 
their personal venality, the danger of the English system of finance was to fundamental liberties, it was systematic corruption. The identification of financial interest with the Crown was the mechanism of corruption.

Hamilton's arguments for America's new financial system had ominous overtones. In the Report on the Public Credit in January 1790, Hamilton proposed that "If all the public creditors receive their dues from one source... their interests will be the same. And having the same interests, they will unite in support of the fiscal arrangements of the government." 31 Hamilton proposed precisely the type of arrangement with the monied interest that commonwealthmen feared in Britain. A typical response to Hamilton's proposals came from the Virginia legislature's memorial to Congress on December 16, 1790:

That it is with great concern they find themselves compelled, from a sense of duty, to call the attention of Congress to an act of their last session, entitled "An act making provision for the debt of the United States," which the General Assembly conceives neither policy, justice, nor the constitution, warrants. Republican policy, in the opinion of your memorialists, could scarcely have suggested those clauses in the aforesaid act, which limit the right of the United States, in their redemption of the public debt. On the contrary, they discern a striking resemblance between this system and that which was introduced into England at the Revolution - a system which has perpetuated upon that nation an enormous debt, and has, moreover, insinuated into the hands of the Executive an unbounded influence, which, pervading every branch of the Government, bears down all opposition, and daily threatens the destruction of every thing that appertains to English liberty. The same causes produce the same effects.

In an agricultural country like this, therefore, to erect and concentrate and perpetuate a large moneyed interest, is a measure which your memorialists apprehend must, in the course of human events, produce one or other of two evils: the prostration of agriculture at the feet of commerce, or a change in the present form of Federal Government, fatal to the existence of American liberty. ${ }^{32}$

The Virginians questioned whether "Republican policy," i.e. commonwealth ideas, could have suggested such a financial program, draws a direct connection between Hamilton's plan and English executive corruption which has "insinuated into the hands of the Executive an unbounded influence." In typical whig style, the memorial raises the alarm that Hamilton's 
plans threaten the "existence of American liberty."

As Banning noted, it would have been difficult to consciously design a financial program that provoked commonwealth fears of executive influence more directly than Hamilton's. Nonetheless, Congress passed all the plan's elements. Washington polled his cabinet on the constitutionality of the legislation. Attorney General Randolf and Secretary of State Jefferson opposed the bank charter, arguing that the Constitution did not explicitly enumerate the power of the government to create a corporation. Treasury Secretary Hamilton argued that the power to create a corporation was inherent in the powers of a sovereign government. ${ }^{33}$ Hamilton's arguments carried the day and Washington signed the charter bill into law.

Although Hamilton's proposals were controversial, they all passed. But a debate about the implications of the financial plan immediately flared up and revealed several inherent contradictions in the system devised by the founders. On the Federalist side the Adamses, joined by Hamilton, praised the British constitution and argued against extending democracy too far. On what would become the Republican side, Jefferson and Madison, abetted by Thomas Paine and Phillip Freneau, attacked the Adams' as monarchists and Hamilton as an aspiring Prime Minister. The Republicans castigated the financial plan as an attempt by Hamilton to use his position as Treasury Secretary to secure control of the government through systematic corruption. Public acrimony between the participants set in motion the formation of distinct Federalist and Republican parties in national politics. The way in which the conflict was resolved placed corruption in government promotion of economic development at the center of American politics for the next half century, and brought to prominence several contradictions in the American experiment with republican government:

1) Popular Sovereignty vs. Tyranny of the Majority. Both the Federalists and the Anti- 
Federalist argued for popular sovereignty as a critical element in the new American system. Sovereignty, lodged with the people, could be delegated to representatives through election. Yet ultimately sovereignty remained in the hands of the voters. But to those trained in the ways of commonwealth theory, tyranny of the many was just as much a problem as tyranny of the one or the few. The exercise of popular sovereignty necessarily involved the risk of tyranny of the majority, a risk that Madison and Hamilton both appreciated. Madison hoped the extended republic would mitigate the risk, as he argued famously in Federalist \#10. The greatest danger from majority rule lay in the possibility that a demagogue would arise, unify a majority of the voters behind him, and lead the government into despotism. Such a leader might over ride the checks and balances built into system by sweeping a majority through all the branches of government. Madison's hopes didn't last a decade, by the early 1790s the Federalists controlled all three branches of the national government. ${ }^{34}$

2) Political Parties vs. Corruption. The Constitution itself offered a way for Jefferson and Madison to oppose the Federalists: the formation of a opposition party. The logic of the winner take all electoral process for President, as well as other offices, seemed to guarantee that eventually two competing parties would emerge. ${ }^{35}$ And despite the strict separation of executive and legislative functions in the constitution, the President and Congress still had to find a way to come to an agreement about how government was to be carried out, a coordination eventually accomplished through parties. But the formation of an overt political party challenge the incumbent Federalists, who could plausibly argue that their administration was non-partisan, carried with it an explicit danger. Parties and factions were inherently, systematically corrupt. For a party to contest for control of the government in an organized way was per se corrupt in the 1790s. Madison, in a series of articles published in the National Gazette, provided an 
intellectual justification for parties. ${ }^{36}$ Madison drew on the classic distinction between the few and the many, arguing that the Republicans represented the many.

But a much stronger argument was to obviate the need for parties at all. Madison and the entire Republican party claimed that they stood on the side of the angels in a debate over republican vs. monarchical government and pure vs. corrupt methods of governing. ${ }^{37}$ Tarring Adams and the Federalists with being closet monarchists played well to some voters, but it was the fear of executive influence in the legislature, wielded by Prime Minister Hamilton through the coordinating mechanism of the Bank of the United States and the national debt that posed the greatest threat. It was a threat that resonated with a century of British political writing and the decades of American paranoia over corruption in the Britain. The negative political implications of the Republicans existence as an organized political party could be minimized by stressing the rightness of their cause. "The situation of the public good, in the hands of two parties nearly poised as to numbers, must be extremely perilous. Truth is a thing, not of divisibility into conflicting parts, but of unity. Hence both sides cannot be right. Every patriot deprecates a disunion, which is only to be obviated by a national preference for one of these parties. ${ }^{" 38}$ If the Republicans were truly right, then their cause was not a partisan one but a righteous one, and when the country came to see the wisdom of their position there would no longer be a need for competing parties.

3) Corruption vs. Promotion of Economic Development. By building their case against Hamilton and the Federalists along traditional Whig lines, the Republicans gained the moral force of a century of British/American thinking about corruption in government. At the same time, they boxed themselves into a fundamental dilemma. The Republicans were just as much a pro-growth and development party as the Federalists. Their arguments against the Federalists 
were political, not economic. They were not arguing that Hamilton's plan wouldn't work in economic terms, but that Hamilton was taking the first step down the slippery slope to executive tyranny. How then did the Republicans propose to promote economic development?

The only one model available at the end of the $18^{\text {th }}$ century had been used by governments to promote economic development for centuries, in Britain and elsewhere: by creating public service corporations. Those corporations were given public privileges in order to induce them to provide public services. Their public privileges generated private rents by limiting entry. Drew McCoy’s book, Elusive Republic, makes abundantly clear that the central tenets of Jefferson and Madison's economic vision required the construction of a financial and transportation infrastructure to bring the agrarian west into viable production. At the same time, foreign economic policy had to insure growing external markets for American products abroad, so that yeomen farmers did not produce themselves into poverty. ${ }^{39}$ There was no institutional vehicle to promote financial and transportation improvements but the corporation. If the Republicans were to condemn the corporation as an instrument of corruption at the national level, they left themselves without a way of promoting the very economic development that they sought and that voters demanded.

None of these contradictions were resolved in the first forty years of the country's history, all of them resolved themselves in the 1830 s and 1840 s.

\section{$* * * * *$}

Perhaps party competition between the Federalists and Republicans could have culminated in a resolution of the contradictions of American democracy in the early 1800 s. The triumph of Jefferson over Adams in 1800 and the Republican's ability to form a consensus 
national government obviated the need to form a partisan political party. By the War of 1812 the Republicans had firm control of the national political agenda. and so put off the paradox of corruption and political parties at the national level until 1824. The Republican's ability to govern by apparent consensus papered over the threat of a tyrannous majority by governing as a virtuous majority. Geographic, if not partisan, divisions soon appeared in Congress. The inability of the federal government to overcome the problem of internal geographic competition produced inaction at the federal level. ${ }^{40}$ Responsibility for promoting development fell squarely on the states. The resurgence of national party politics in the $1820 \mathrm{~s}$ and $1830 \mathrm{~s}$, was fought between the Democrats and Whigs over economic issues and, fundamentally, over systematic corruption. Again, the national government failed to provide active leadership and, in the 1840s, it was state governments that finally solved the paradox promoting economic development while avoiding systematic corruption.

I) State governments expanded their involvement in banking and transportation from 1790 onward. ${ }^{41}$ It is tempting to attribute the rise of state promotion to the absence of federal promotion, but it seems clear that state activity was a continuation of the development of government capacity at the state level that began in 1776 with the call for new state constitutions. States began chartering banks, turnpike companies, bridge companies, fire companies, and all manner of religious, charitable, educational, and municipal corporations in the 1790s. ${ }^{42}$ By 1836, when the national charter for the Second Bank of the United States expired, there were over 600 state chartered banks. In the meantime, the federal government had chartered the First and Second Banks of the United States and a few small banks in the District of Columbia. ${ }^{43}$ Between 1790 and 1860, state and local governments spent $\$ 450$ million, financing the Erie Canal, the Baltimore and Ohio railroad, hundreds of other successful projects 
as well as hundreds of failures. Over the same period, the federal government spent $\$ 54$ million on transportation improvements, mostly small rivers and harbor projects. In 1841, aggregate state debts stood at $\$ 198$ million, larger than the national debt had ever been.

Corporate charters were, of course, grants of special privileges to small groups of citizens. Initially, every charter required an act of the state legislature and all corporations were, in the language of the time, special. Charters always raised the specter of corruption and strong anti-charter sentiments were usually expressed whenever a charter was contemplated. ${ }^{44}$ At the same time, there was wide spread public sentiment for promoting economic development, and the corporation was seen as the vehicle for state promotion. As a result, corporate chartering policy often contained contradictory elements.

Although anticharter arguments were frequently stated as if they applied to all corporations without exception, in practice opposition usually settled on some corporations only. Even the Pennsylvania legislators who campaigned against the BNA and the reincorporation of Philadelphia [the city] apparently raised no objections to the charters granted "every day," as one legislator put it in 1786, to "half a dozen or 20 people for some purpose or another." Similarly, in 1792 James Sullivan carefully distinguished the incorporation of a bank from that "to build a bridge, or to cut a canal," which he found unobjectionable. Banks were probably assailed more often than any other kind of corporation. But consider the position of a delegate to the Massachusetts constitutional convention of 1853 who launched a rhetorically powerful attack on corporations "of a business character." Among corporations "for other purposes," which were apparently exempted from his criticisms, he included railroads, insurance companies and banks!" 45

The right to assemble, the right to organize, was explicitly recognized by early American states. Their charter policies reflected public support of private organization. In itself, this made a significant, if unmeasured, to the development of the American economy. ${ }^{46}$

But granting corporate charters was not without its costs, real and potential. In New York the Albany Regency, headed by Martin Van Buren, used bank charters to dominate state politics. ${ }^{47}$ The Regency granted bank charters only to their political allies. In return, the bankers 
provided financial support to the Regency, enabling the Regency to maintain control of state government. It was a classic case of systematic corruption: a group of politicians using economic privileges to secure their control of the political system. New York was not unique. Unlike New York, however, most states that created rents through by limiting entry chose to take their share of the rents in the form of tax revenues, not political influence. ${ }^{48}$

II) The election of 1824 offered a chance to change the course of federal policy. The election was contested by William Crawford, John Quincy Adams, Henry Clay, and Andrew Jackson. Corruption was the theme of Jackson's campaign:

Look to the city of Washington, and let the virtuous patriots of the country weep at the spectacle. There corruption is springing into existence, and fast flourishing, Gentlemen, candidates for first office in the gift of a free people, are found electioneering and intriguing, to worm themselves into the confidence of members of congress, who support their particular favorites, are bye and bye to go forth and dictate to the people was is right. $^{49}$

Jackson won a plurality of the popular vote and the electoral vote. When the election went to the House, however, Clay threw his support behind Adams. Adams was elected and appointed Clay Secretary of State. Jackson decried the "corrupt bargain," "So you see, the Judas of the West [Clay] has closed the contract and will receive thirty pieces of silver. His end will be the same. Was there ever witnessed such a bare faced corruption in any country before?"50 Jackson's campaign for the 1828 election began in 1824 , and its theme was corruption.

John Quincy Adams strongly supported internal improvements in 1825. His administration spent more on internal improvements than any before him, but Congress refused to authorize a general system of federally sponsored transportation projects. Jackson's election in 1828 did not necessarily signal the end of hope for a more active federal government, but it did bring back into clear focus the three contradictions of American democracy. General Jackson was the epitome of the man on horseback who, to his enemies, offered the perfect image 
of a demagogue and the dark side of democracy. The Democratic party built to elect Jackson did not disappear after 1828; competitive party politics became a permanent part of American politics and raised the specter of corruption, faction, and party. Finally, the opposition party that emerged during Jackson's first term, what became the Whig party headed by Henry Clay and initially financed by Nicolas Biddle, chose to contest Jackson in the arena of economic policy. The first defining question for Whigs and Democrats was whether the national government should renew the charter of the Second Bank of the United States.

The economic and political history of the Bank War is well known. ${ }^{51}$ The debate between Jackson and his opponents was carried out in terms of systematic corruption. Jackson's veto message railed against the special privileges conveyed to the Bank. The veto message laid out Jackson's position on the Bank, on the battle between the aristocratic wealthy and the masses of the population, and on the abuse of privilege as an evil of government. ${ }^{52}$ But he did not begin speaking of systematic corruption until the Bank War broke into open conflict with his plans to remove the federal deposits. On September 18, 1833 Jackson had Secretary Taney read a statement to the Cabinet that the Jackson and Taney had prepared on the why the deposits should be removed:

The Bank of the United States is in itself a Government which has gradually increased its strength from the day of its establishment. The question between it an the people has become one of power - a question which its adherents do not scruple to avow must ultimately be decided in favor of the Bank... The mass of people have more to fear from combinations of the wealthy and professional classes - from an aristocracy which thro' the influence of riches and talents, insidiously employed, sometimes succeeds in preventing political institutions, however well adjusted, from securing the freedom of the citizen, and in establishing the most odious and oppressive government under the forms of a free institution." 53

Jackson recalled the classic phrases of systematic corruption. The Bank itself was a government: a small group (in this case Biddle and Clay) using the powers of government to create a powerful 
economic interest, and gains from monopoly rents thus created were being used to subvert the process of government and threaten the liberties of all citizens by establishing an odious and oppressive government.

His opponents replied in kind. In the election of 1832, they styled themselves National Republicans, and by late 1833 the Whig party was born. In a speech in December 1833 protesting Jackson's removal of federal deposits, Henry Clay concluded:

The eyes and the hopes of the American people are anxiously turned to Congress. They feel that they have been deceived and insulted; their confidence abused; their interests betrayed; and their liberties in danger. They see a rapid and alarming concentration of all power in one man's hands. They see that, by the exercise of the positive authority of the Executive, and his negative power exerted over Congress, the will of one man alone prevails, and governs the republic. The question is no longer what laws will Congress pass, but what will the Executive not veto? The President, and not Congress, is addressed for legislative action... We behold the usual incidents of approaching tyranny. The land is filled with spies and informers, and detraction and denunciation are the orders of the day. People, especially official incumbents in this place, no longer dare speak in the fearless tones of manly freemen, but in the cautious whispers of trembling slaves. The premonitory symptoms of despotism are upon us; and if Congress do not apply an instantaneous and effective remedy, the fatal collapse will soon come on, and we shall die - ignobly die - base, mean, and abject slaves; the scorn and contempt of mankind; unpitied, unwept, unmourned! $!^{54}$

Clay did not accuse Jackson of venal corruption. In the language of the commonwealth the Whigs charged Jackson with executive usurpation, of corrupting the political process. Tyranny and slavery would follow.

The contest between Clay and Jackson, and the longer struggle between the Whigs and the Democrats was fought over classic commonwealth concerns: executive usurpation, the monied conspiracy, corporations, and the appropriate role of government in promoting economic development. The major issues between Democrats and Whigs were economic, but the foundation for the debate over economic policy was a larger debate over systematic corruption. Both sides of the Bank War debate painted the other side as systematically corrupt. 
Jackson's administration resolved two of the paradoxes of American democracy. First, from Jackson onward, demagogues were accepted, as long as they were elected President. ${ }^{55}$ Jackson permanently increased the power of the Executive branch. He claimed that the President most effectively represented the collective will of the entire people as shown in the only nation wide election. Second, political parties became an accepted part of the political system. Suspicion of partisan motivation and the dangers of faction and party remain to the present day, of course. ${ }^{56}$ But the national government could not resolve the third paradox -- corruption and the promotion of economic development. Jackson solution to corruption in banking was to not have a bank. This continued the existing federal policy of inaction. Except in the earliest days of the Washington administration the national government, Congress and Executive, were unable to design or execute a program of active government promotion of economic development.

III) Promoting economic development was left to the states. By the end of Jackson's second term, states throughout the country were deeply involved in investing in and promoting banks and transportation systems. The investment boom of the 1830 s was ended by the depression that began in 1839. By 1842, eight states and the territory of Florida were in default. The crisis in public finance naturally brought investigations into its causes. Venal corruption caused fiscal problems in a few states: Mississippi, Florida, and Arkansas. Most states, however, blamed faulty institutions: they blamed it on how democracy was working out in practice. ${ }^{57}$

American state governments were the first governments of their kind in history.

Governed by written constitutions, they operated within the framework of a national government that provided military defense and international relations, a basic legal system, and very little else. States believed that republican government was good. They wanted to promote economic growth, but they worried incessantly that the corporations and privileges they created to promote 
growth benefitted a favored few to the detriment of the many and undermined the integrity of their governments. States were forced to solve the paradox of corruption and the promotion of economic development. Their solution was elegantly simple: let everybody have a corporate charter who wants one.

Their history endowed American state governments and their citizens with the idea that some problems of government were not caused by bad men, but by bad governments. They were Aristotelian and Polybian in their understanding that the constitution of a government, the stamina vitae, created incentives for the actors, politicians and citizens, to pursue particular ends. They were the first modern people to possess extensive experience with written constitutions. ${ }^{58}$ The early nineteenth century was an era of continual political debate about the structure of government.

States were the first governments with extensive experience in chartering corporations. The first and most important connections between governments and corporations were fiscal. This was true in Britain and the mercantilist privileges that Adam Smith complained about. It was true in the American states from the beginning. If governments were going to sell monopoly privileges and corporate charters for revenue, then inevitably each charter required a price, a negotiation, a bargain. ${ }^{59}$ This was a systemic feature of any system of government where charters created limited entry into a line of business. Democratic governments could create and sell corporate privileges. Taxpayers liked receiving government services paid for by charter fees, taxes on capital, or dividends on stock. But by its very nature the creation of corporate privileges created the opportunity for political groups to create economic privileges that could be used to distort the political process. This happened in Britain with the national debt, it happened in New York with the sale of bank charters to the political friends of the Albany Regency, it was 
a systematic feature of any government that sold corporate privilege. State governments came to understand that if they remained in the market for selling corporate charters, if they remained willing to consider developers proposals that promised tax free provisions of railroads and banks, that inevitably some politicians, even well meaning politicians, were going to make some serious mistakes. Voters could easily be induced to vote for expenditures that promised large returns without levying taxes. States also came to understand that allowing entry reduced the rents associated with corporate privileges, without eliminating the wider social benefits of creating corporations.

The state's solution the paradox of corruption and economic development was as simple as it was ingenious. First, states eliminated the pressure to create special corporate privileges by enacted constitutional provisions requiring legislatures to pass general incorporation laws allowing unlimited entry into corporate status via an administrative procedure. Second, states passed constitutional provisions requiring that all state borrowing required a bond referendum: mandating that the higher taxes necessary to service the bonds be approved by the voters before the bonds were issued. Third, most states forbade state and local investment in private corporations. Between 1841 and 1852, twelve states wrote new constitutions. Eleven of the twelve contained procedural debt restrictions and eight mandated general incorporation acts. In banking, general incorporation acts produced free banking (the first free banking acts were in Michigan and New York in 1837 and 1838). Nine states prohibited incorporation by special legislative acts altogether, prohibiting state legislatures from creating corporations with special privileges. $^{60}$

The point of these reforms was not to eliminate state and local government investments in finance and transportation. Governments could borrow as long as they were willing to raise 
taxes. The reforms were not designed to limit the creation of corporations. General incorporation acts made it much easier to get a charter. The reforms were designed to reduce or eliminate the private economic rents that were created when the political system limited entry. The reforms intended to reduce the political manipulation of the economic system, not by making such manipulations illegal or unconstitutional, but by reducing the payoff to political machinations. Institutions supporting unlimited entry, free competition, and competitive markets were put in place by American states in the 1830s and 1840s. They were the solution to a political problem, not an economic problem. The effect of the reforms, however, was to put in place a critical institutional underpinning of modern economies. It was the uniquely American solution to the paradox of systematic corruption and the promotion of economic development.
Almost any history textbook that covers the Progressive era and was written at least twenty years ago tells how early-twentieth-century Americans discovered how big business interests were corrupting politics in quest of special privileges and how an outraged people acted to reform the perceived evils.
Richard L. McCormick, "The Discovery that Business Corrupts Politics,” 1981, p. 247
By the Progressive era corruption was no longer systematic corruption: the corruption of economics by politics. It was, as the title of McCormick's essay suggests, venal corruption: the corruption of politics by economics. The Civil War, the rise of an integrated national economy, and the development of a thriving manufacturing sector all could have unbalanced and corrupted America's governments. But they did not produce tyranny or dictatorship and by tghe $1890 \mathrm{~s}$ Americans had become more confident in the resilience of their system of government. Corruption no longer seemed to be an infra-marginal threat; the system was no longer at risk. When progressive reformers complained about the evils of big business's influence on politics, they no longer suggested that slavery and tyranny were just around the corner. Their confidence 
in the American system was reflected in the constitutional changes made during the era: at the national level the direct election of Senators by popular vote and women's suffrage, and at the state and local level by the spread of initiative, referendums, and recalls and the rise of home rule. Progressive era constitutional reforms all emphasized an increased role for popular participation in the political process, reforms that were unthinkable a century before.

Benjamin Parke DeWitt, progressive reformer and historian, wrote in his Progressive Movement: A Non-partisan, Comprehensive Discussion of Current Tendencies in American Politics in 1915:

In this widespread political agitation that at first sight seems so incoherent and chaotic, there may be distinguished upon examination and analysis three tendencies. The first of these tendencies is found in the insistence by the best men in all political parties that special, minority, and corrupt influence in government - national, state, and city - be removed; the second tendency is found in the demand that the structure or machinery of government, which as hitherto been admirably adapted to control by the few, be so changed and modified that it will be more difficult for the few, and easier for the many, to control; and, finally, the third tendency is found in the rapidly growing conviction that the functions of government at present are too restricted and that they must be increased an extended to relieve social and economic distress. These three tendencies with varying emphasis are seen to-day in the platform and program of every political party; they are manifested in the political changes and reforms that are advocated and made in the nation, state, and the cities; and because of the universality and definiteness, they may be said to constitute the real progressive movement. (DeWitt, 1915, pp. 4-5).

The first Progressive tendency -- that special, minority, and corrupt influence in government be removed -- could have been written in London in 1720, Philadelphia in 1787, Albany or Indianapolis in the $1840 \mathrm{~s}$, or today for that matter. The venal are always be with us and venal corruption can only be prevented by eternal vigilance. The third tendency, a call for government policies to relieve social and economic distress translated into new social programs like workmen's compensation and mother's pensions in the 1900s and 1910s, but reached its full measure in the New Deal. ${ }^{61}$

The second tendency, to make changes in the structure and machinery of government, 
constituted the heart of the Progressive reform agenda. DeWitt's language indicates the distance that Progressives had come from Commonwealthmen. The structure of machinery of government "be so changed and modified that it will be more difficult for the few, and easier for the many, to control.” A century earlier such a suggestion would have been a call for unbalanced government -- in short, a call for corruption. The Progressive movement was an anti-corruption reform movement, promoting policies the founding fathers would have regarded as corrupt. The progressive movement produced reforms in three distinct constitutional areas. First, the Progressives altered the relationship between corporations and governments through active regulation and changes in chartering. Second, they expanded direct participation in government; at the national level through women's suffrage and the direct election of Senators; and at the state and local level through the initiative, referendum, and recall to bring direct democracy into the policy process. Third, they altered the relationship between state and local governments through home rule amendments and the local charter movement. These reforms shared several elements. They allowed both public and private sector organizations more flexibility to choose the form of their internal organization. They increased the acceptable range of interaction between government and the economy, allowing governments to interfere and regulate business, or withdraw their regulation. Finally, the entire process was to be monitored by a more democracy, by putting more power in the hands of the many. The Progressives believed in balanced government. But it was the checks and balances of the national and state constitutions, not the balance of social orders and classes reflecting the interests of the one, the few, and the many.

State chartering policy links the Progressive era and the Jacksonian era. The widespread adoption of general incorporation acts in the 1840s liberalized access to corporate charters and 
the number of corporations in America exploded, relative to both early American history and contemporary European economies. ${ }^{62}$ But general incorporation acts liberalized entry while putting more severe restrictions on the structure of corporations. All corporations created under a general act shared common features. In states that banned special incorporation altogether, a corporation that wanted to change its internal voting rules, shareholder rights, or its management structure was severely constrained. ${ }^{63}$ For example, corporations were typically prohibited from owning stock in corporations domiciled in other states. All this began to change in New Jersey in the late $1880 \mathrm{~s}^{64}$

In a series of acts between 1888 and 1896, New Jersey created liberal general incorporation. These acts allowed corporations to merge and hold stock in other corporations, to operate outside of the state, and to create define their internal structure within much wider bounds. Corporations flocked to New Jersey, swelling the state's revenues, and opening up new opportunities for corporate structure throughout the country. ${ }^{65}$ What followed was the great merger movement. Between 1895 and 1904 there was a rapid consolidation of the nation's largest manufacturing firms. Over half of the consolidations involving more than $\$ 1$ million in capital took place in New Jersey. ${ }^{66}$ New York and Delaware soon followed New Jersey's lead, liberalizing their incorporation laws and trying to lure businesses into their states.

Attributing the Progressive era to the merger movement would be silly, although there is a remarkable coincidence of timing. "Yet, given the long-term forces involved, it is notable how suddenly the main elements of the new political order went into place. The first fifteen years of the twentieth century witnessed most of the changes; more precisely, the brief period from 1904 to 1908 saw a remarkably compressed political transformation. During these years the regulatory revolution peaked; new and powerful agencies of government came into being 
everywhere.” (McCormack, 1981, p. 252) When a small number of unprecedentedly large corporations sprang into being during the merger wave the national and state governments responded to the public perception that corruption was again a problem in American politics. But they responded much differently in the first decades of the twentieth century than they had before.

Battling venal corruption and regulating the excesses of the plutocrats charged the progressive movement with a populist morality. It is striking how much of the Progressive rhetoric, perhaps in combination with the symbols of the temperance movement, focuses on bad men rather than on bad institutions. Giving more control to the many was the mechanism by which "special, minority, and corrupt influence in government - national, state, and city [could] be removed." The constitutional machinery of the progressive constitutional reforms were electoral and democratic. At the national level, the direct election of Senators by popular majorities and suffrage for women were the key progressive accomplishment. At the state level, the adoption of the initiative, referendum, and recall gave voters direct control over legislation and officials. Initiative, referendum, and recall were adopted at the local level as well, but the critical change was the widespread adoption of home rule provisions and new methods of chartering local governments. These transferred control of local governments from state to local governments, providing voters with the ability to directly shape local government policies to suit the ends of local majorities.

The medicine prescribed by progressives to cure systematic corruption would have seemed insane to a founding father. Systematic corruption flowed from the ability of politicians to use the economic system to further their political ends. Electoral excess, tyranny of the majority, and mob rule were serious threats that had to be balanced by the creation of other 
centers of power in the political system. All of the Progressive's constitutional reforms strengthened direct popular participation in political decision making. Of course, the progressives did not dismantle the checks and balances of the Madisonian system, nor did they dismantle the constitutional reforms that required popular approval of state and local debt issue and therefore spending. But the idea of balancing the interests of the one, the few, and the many had disappeared completely, as did the fear that democracy itself is corruptible. Progressive reforms celebrated popular sovereignty, the concept that the voters were the ultimate judge of government policy. Deciding whether politicians and policies were venally corrupt would be left to popular choice. The many would decide whether the few had violated their mandate to govern on behalf of the common good. Majorities really would rule.

How could this happen? The constant element in earlier discussion of corruption in America and Britain was that corruption inevitably leads to tyranny and slavery. Patrick Henry could hear the chains clinking on the plains of Boston in 1775, Henry Clay feared that we would "all die - ignobly die - base, mean, and abject slaves" if Congress allowed Jackson to remove the federal deposits from the Bank of the United States. Such language is not to be found in the progressive era.

Between 1840 and 1890 American crossed a divide. On the early side of the divide governments could never be trusted. Politicians would always, if the chance presented itself, use the powers of government to manipulate the economic system in order to consolidate their control of the political system. Consolidation of political control upset the delicate balance of government and, with Polybian certainty, led to tyranny and slavery. Balance in government could never be assumed. Small changes in the distribution of power could quickly lead to imbalance. The defense of liberty required eternal vigilance. On the later side of the divide, 
balance in government is no longer fragile. Tyranny and slavery are still possibilities, but highly improbable ones. By allowing, indeed mandating, more competition and entry in the economic and political system, Madison's extended republic, as modified by the states, had produced a stable balance within government.

In classical Whig political economy, increasing government regulation raised as many red flags as did special corporate charters. Regulation created the opportunity for creating rents; rent creation created the possibility for political manipulation of the economy. One could see James I or Charles II promoting these changes in government, not Whig commonwealthmen. If, on the other hand, political and economic competition limit rent creation and dissipation, they also make it safer for the government to regulate in positive and negative ways. Competition and entry create their own balanced equilibrium.

This could only have happened if Americans came to trust their government more than they ever had in the colonial, revolutionary, or early national periods. ${ }^{67}$ Progressive era reforms increased political entry by widening the scope of popular democratic political institutions: direct election of senators, women's suffrage, the initiative, the referendum, the recall, and home rule. At the same time progressive era policy reforms created much wider opportunities for rent seeking by politicians and economic actors, trusting, apparently, that voters could monitor the new powers given to their representatives. The threat of systematic corruption, so prevalent for three centuries in British and American political and economic thinking, had receded to the point of disappearance from the political debates of the Progressive era.

\section{$* * * * * * *$}

One way to think about developing countries is that they are are poor because the government officials are venally corrupt. If only the right people and policies could be put in 
place, economic growth would ensue. A more pessimistic and realistic view is that developing countries are plagued with systematic corruption. They are plagued by governments that systematically manipulate the economy to produce economic rents that further the political interests of the people and parties in power. This is not a matter of bad people causing problems. This is a fundamental flaw in the constitutional structure, the stamina vitae, of these societies.

The United States came by its fear of systematic corruption legitimately. It was born in a constitutional crisis rooted in Whig/Commonwealth paranoia about the threat to fundamental liberties of all Britons embodied in executive usurpation of Parliamentary independence. The emerging institutions of modern financial capitalism - a national debt, a central bank, a stock market, and a host of financial intermediaries - were not the causes of corruption. The institutions of modern financial capitalism were the instruments of systematic corruption, tools in the hands of the Crown and its evil ministers. British corruption threatened fundamental liberties. The storm warnings of tyranny and slavery were flying in 1776 .

The founding fathers seized the first chance to write their own constitutions in 1776, crafting a series of state constitutions implementing Whig precepts of balanced government. They didn't get it completely right the first time. Between 1776 and 1852 the original 13 states wrote 29 constitutions. The national government took two tries as well: the Articles of Confederation written in 1777 and the Philadelphia constitution written in 1787. Congress implemented Hamilton's financial plan in 1791 deliberately modeled on the British financial system: a national debt, a central bank, and assumption of state debts. Within a year, national politics fragmented over the charge that Hamilton and the Federalists were establishing a Prime Ministry with Hamilton at the center of a web of influence and interest. The national government remained gridlocked for decades over how, and whether, economic development 
should be promoted. When the national government's experiment in central banking came to an end with Jackson's veto of the charter of the Bank of the United States in 1832, the issue was still systematic corruption. Clay claimed that "we shall die - ignobly die - base, mean, and abject slaves; the scorn and contempt of mankind; unpitied, unwept, unmourned!" if Jackson went unchecked.

Meanwhile, in the 1790s states began chartering banks, churches, and all varieties of corporations. By the 1820 s states were building canals, experimenting with railroads, borrowing money, and investing their own funds in corporations. By the 1830 s there were over 600 state chartered banks and state debt for internal improvement investment was double the national debt accumulated in the Revolution and the War of 1812. State activism did not go unchallenged. Corporations were still regarded as potential vehicles for corruption. Bank chartering under New York's Albany Regency was a classic example of systematic corruption: a political faction using the creation of economic privilege to secure their control of the political system. The central theme in Jackson's rise to prominence was an attack on corruption, an attack on government created privilege.

When the internal improvement boom collapsed after 1839, states carefully re-examined the policies that led them to issue $\$ 200$ million in state bonds. States again turned to their constitutions and implemented a series of reforms that mandated general incorporation acts guaranteeing free entry into corporate privileges, modified the procedures by which state and local government decided to borrow money, and prohibited government investment in private corporations. With a few exceptions, the constitutional reforms were not bans on state promotion of economic development. They did not prevent governments from chartering banks, building canals or railroads, or in the progressive era building municipal water systems, sewer 
systems, ans school systems. Constitutional reforms were explicitly designed to cut away the roots of systematic corruption by limiting the government's ability to create economic rents through limiting entry and granting special economic privileges.

Republican and Federalists in the 1790s, Whigs and Democrats in the 1840s, were just as concerned with venal corruption as the Progressive would be in the first decade of the $20^{\text {th }}$ century. But venal corruption was not the most dangerous problem facing America before the Civil War. Tyranny and slavery were all around the world of the early $19^{\text {th }}$ century. France went from absolute monarchy, to revolution, to dictatorship, and back to monarchy. Spain's New World empire collapsed in a wave of revolutions, many inspired by the United State's example. New world revolutionary governments often adopted constitutions explicitly modeled on the United States: checks and balances and separation of powers included. But tyranny, not liberty, was typically the fruit of revolution in Latin and South America. The national and state governments probably never had truly systematically corrupt governments (the Albany Regency included), but Americans feared that any movement away from balanced government would bring, with Polybian certainty, a erosion of republican government and the rise of tyranny and slavery.

By 1890, however, not only was the American experiment in limited government a demonstrable success, but the country's institutions had persisted through a bloody Civil War, liberty intact, and chattel slavery ended. Fear of tyranny and slavery was justifiably receding. A modern industrial economy and the world's largest integrated market posed a new set of problems for governments. After tentative first steps at regulation in the 1870 s and 1880 s, the national government effloresced in the first half of the twentieth century, as the papers in this volume show so clearly. Giving the national government control over food and drugs would 
have seemed insane to the founding fathers, Federalist and Republican. Such regulation opened up vistas of rent creation beyond the imagination of James I or Charles II.

Yet, for all the fear of corruption that filled the rhetoric of Progressive reformers, the corruption documented so ably in this volume is distinctly venal corruption. The Progressives were not afraid that a faction within government would use the creation of economic privileges to seize control of the government. They were concerned that economic interests were using their growing size to wrest concessions from governments. They worried about the efficiency of American government, about the quality of representation, of equity, access, and fairness. They worried that economics corrupted politics. They did not worry about tyranny and slavery.

The landmark accomplishment of the western democracies in the $19^{\text {th }}$ and $20^{\text {th }}$ century has been the creation of stable limited government. No society with a systematically corrupt political system has limited government. The economic system is always at risk, entry is limited, competition is fettered, and economic policies are shaped by politicians to maintain their political control of the government. Crony capitalism is not just a manifestation of venal corruption, it is a symptom of systematic corruption. Developing countries do not have markets that work well, because the free entry and competition that are necessary to making impersonal markets work cannot flourish when entry is limited to create the privileges that hold the political system together. What lessons does the United States have to teach about corruption? The fundamental lesson is how to construct a government that does not depend on manipulation of the economy for its continued existence. 
1. "In the process, the rhetoric of corruption emerged as the common grammar of politics, so overwhelming that it became difficult to discuss public questions in any other language. The age of Jefferson bequeathed to the United States an obsession with corruption that still deeply colors the way we think about politics." Murrin, 1994, p. 104.

2.Shleifer and Vishny, 1993, p. 599. For other treatments of corruption see Klitgaard, 1988; Rose-Ackerman, 1978; and Clague, 2003.

3. "These widely voiced fears for the fate of the English constitution, "the mighty ruin of a once noble fabrick," were not simply the bombastic expressions of revolutionary-minded men. They represented the rational and scientific conclusions of considered social analysis. For all of its rhetorical exaggeration, the ideology of Whig radicalism, embraced by Americans of varying political persuasions and at every social level, was grounded in the best, most enlightened knowledge of the eighteenth century; it was this grounding that gave the Whig ideology much of its persuasive force. When the American Whigs described the English nation and government as eaten away by "corruption," they were in fact using a technical term of political science, rooted in the writings of classical antiquity, made famous by Machiavelli, developed by the classical republicans of seventeenth-century England, and carried into the eighteenth-century by nearly everyone who laid claim to knowing anything about politics.” Wood, 1969, p. 32.

4.Pocock's work is fundamental for understanding the evolution of ideas about balanced government and corruption. The argument is completely developed in The Machiavellian Moment.

5. Aristotle appreciated venal corruption as well. "The conclusion is evident: that governments which have a regard to the common interests are constituted in accordance with strict principles of justice, and are therefore true forms; but those which regard only the interests of the rulers are all defective and perverted forms." Aristotle, Politics, Book III, 1279ª p. 71.

6. We speak of a persons with a hearty constitution or with a fragile constitutions. Constitutions were like bodies. "Like their contemporaries in England and like their predecessors for centuries before, the colonists at the beginning of the Revolutionary controversy understood by the word 'constitution' not, as we would have it, a written document or even an unwritten but deliberately contrived design of government and specification of rights beyond the power of ordinary legislation to alter; they thought of it, rather as the constituted - that is, existing - arrangement of governmental institutions, laws, and customs together with the principles and goals that animated them. So John Adams wrote that a political constitution is like 'the constitution of the human body'; 'certain contextures of the nerves, fibres, and muscles, or certain qualities of the blood and juices' some of which 'may be properly called stamina vitae, or essentials and fundamentals of the constitution; parts without which life itself cannot be preserved a moment." Bailyn, 1967, p. 68, citing Adams, Works, III, pp. 478-79.

"By constitution we mean, whenever we speak with propriety and exactness, that assemblage of laws, institutions, and customs, derived from certain fixed principles of reason, directed to certain fixed objects of public good, that compose the general system, according to which the community hath agreed to be governed." Bolingbroke, 1997, p. 88. Bolingbroke was 
a leading Tory politician in the early $18^{\text {th }}$ century and an articulate proponent of Commonwealth ideas.

7.See Machiavelli, 1996, Book I, 16, 17, 18; Pocock, 1973, p. 129; and 1975, pp. 83-219.

8.Harrington concluded his "Epistle to the Reader," which opens Oceana, with a theoretical bent: "I dare promise you that if I have not made you a good flight, I have sprung you the best quarry; for though the discourses be full of crudities, the model hath had perfect concoction." (1992, p. 2)

\section{Pocock, 1975 , p. 361}

10.The text of the Answer is printed in Weston, 1965, along with the Political Catechism, a popular document that interpreted the Answer in terms that would become a central part of Whig theory.

11."Charles, when he chose to exert himself, was extraordinarily clever. The role he played during the plot period and during the Exclusion parliaments was that of a wise and skilled politician... Charles came nearer establishing despotism than any member of his family, or indeed any other English ruler." Robbins, 1959, p. 27.

12.This group included Neville, Shaftesbury, Locke, Marvell, and Sidney. These men were contemporaries of Harrington, who died enfeebled and in poor health in 1677 . The prominence of Harrington in this section is a matter of exposition. Harrington ultimately had the most influence, but he was only one of several important commonwealth thinkers. See Robbins, 1959, for a in depth treatment of the men and their ideas.

13.I have drawn on Pocock "Machiavelli, Harrington, and English Political Ideologies" in this section, 1973, pp. 104-147. The argument is developed further in The Machiavellian Moment, 1975, pp. 406-422.

14. Since the influential position of the aristocracy depended on their provision of military service, the country could have an independent nobility or a professional army, but not both. "For the power of Peerage and a Standing Army are like two buckets, the proportion that one goes down, the other exactly goes up..." From A Letter from a Person of Quality to his Friend in the Country, as quoted in Pocock, 1973, p. 118.

15.On the Bank of England and the financial revolution generally see Dickson, 1967; on the bureaucratization of tax collection see Brewer, 1989 ; and for the national debt see North and Weingast, 1989.

16. Mathias and O'Brian, 19??, review the history of government revenues and expenditures in $18^{\text {th }}$ century Britain.

17.This is the theme of Weston, 1965. 
18. "It is certain then, that if ever such men as call themselves friends of the government, but are real enemies of the constitution, prevail, they will make it a capital point of their wicked policy to keep up a standing army.... To destroy British liberty with an army of Britons, is not a measure so sure of success as some people may believe. To corrupt the Parliament is a slower, but might prove a more effectual method; and two or three hundred mercenaries in the two Houses, if they could be listed there, would be more fatal to the constitution, than ten times as many thousands in red and in blue out of them. Parliaments are the true guardians of liberty. For this principally they were instituted; and this is the principal article of that great and noble trust, which the collective body of the people of Britain reposes in the representative. But then no slavery can be so effectually brought and fixed upon us as parliamentary slavery. By the corruption of Parliament, and the absolute influence of a King, or his minister, on the two Houses, we return to that state, and are really governed by the arbitrary rule of one man." Bolingbroke, 1997, pp. 92, 93-4.

19.See the essays on "Parliamentary Patronage," pp. 46-56, and on "Placemen and Pensioners," pp. 118-126 in Namier and Brooke, 1964.

20.The Whigs were opposed political parties as a manifestation of corruption. To confuse matters, At the same time one of the parties that developed in Britain was the Whig Party, which is distinct from the Whig/Commonwealth thinkers. Bolingbroke, for example was a prominent Tory politician as well as a prominent Whig philosopher.

21.Quotations from Wood, 1969, p. 11.

22. "Companies and joint-stocks are always established for the encouragement and benefit of trade; though they always happen to mar and cramp trade." Trenchard and Gordon, 1995, Cato's Letters, No. 9. December 31, 1720; p. 69.

23.Cato's Letters, No. 3, November 19, 1720, pp. 44-5. The title of Letter No. 6, December 10, 1720, conveys the sentiments of Trenchard and Gordon: How easily the People are bubbled by Deceivers. Further Caution against deceitful Remedies for the publick sufferings from the wicked Execution of the South-Sea Scheme.

24.As Dickson summarized: "Finally, it is worth noting that while few aspects of the Financial Revolution were of greater political and economic utility than the development of a market in securities in London, none united contemporary opinion more against it. It was denounced as inherently wicked and against the public interest. The phrase 'stock-jobbing', freely used to denote every kind of activity in the market, had clear overtones of self-interest and corruption. An anthology of comments by contemporaries would be remarkably uniform, indeed monotonous, in its tone, and uninformative about how the market actually worked." 1967, pp. 32-33.

25.Robbins, 1959, quotes from pages 381, 382, and 385 . 
26.Wood, 1969 , p. 10. The republican synthesis literature is neatly summarized and discussed in Shallope 1972 and 1982.

27.The quotation is from a letter from Charles Lee to Robert Morris, Jan. 3, 1776, as quoted by Wood, 1969, p. 32.

28.New Jersey, Constitution of 1776, Article 20. The New Jersey Constitution of 1844 read: Article 3, Section 1: "1. The powers of the government shall be divided into three distinct departments-the legislative, executive and judicial; and no person or persons belonging to, or constituting one of these departments, shall exercise any of the powers properly belonging to either of the others, except as herein expressly provided."

29.This point is developed further in Wallis, 2004B, and Wallis and Weingast, 2004.

30.Joseph Galloway to the Continental Congress, as quoted by Jensen, 1940, p. 66, quoting John Adam's Notes on Debates, Works of John Adams, 2:372.

31."Report on the Public Credit" American State Papers, Finance, Vol I, p. 15. See Ferguson, 1961, for an analysis of how constitutional issues and the public debt interacted in Hamilton's thinking.

\section{American State Papers, Finance, Vol. I, p. 90.}

33.Hamilton wrote "The latter [Randolph], expressly admits, that if there is anything in the bill which is not warranted by the Constitution, it is the clause of incorporation.

Now it appears to the Secretary of the Treasury [Hamilton] that this general principle is inherent in the very definition of government, and essential to every step of the progress to be made by that of the United States, namely: That every power vested in a government is in its nature sovereign, and includes by force of the term, a right to employ all the means requisite and fairly applicable to the attainment of the ends of such power, and which are not precluded by restrictions and exceptions specified in the Constitution, or not immoral, or not contrary to the essential ends of political society." Hamilton's letter to Washington on the Constitutionality of a National Bank, McKee, 1934, p. 101, emphasis in the original.

34. "the success of the Federalist Party in gaining control of all three branches of the national government called into question the fundamental premise of the Madisonian federalism of 17878: that durable factious majorities would be far less likely to coalesce at the national level of politics...." Ferejohn, Rakove, and Riley, 2001, , p. 3.

35."Yet even amid the presumed "paranoia" of the 1790s, with insidious motives being ascribed all around, both Federalists and Republicans opted to seek advantage not through a strategy of exit but rather by exploiting potential opportunities within the Constitution itself. Both parties quickly discovered a strong incentive to convert the untested mechanism of presidential election into an occasion for political innovation. In 1787 no one had expected the presidency to emerge 
as the crucial focus for national political competition, but by 1796 , and even more so by 1800 , it was evident that control of the executive was essential to control of the government." Ferejohn, Rakove, and Riley, 2001, p. 7.

36.In particular see Hofstadter, 1969, p.80-86, and the third chapter "The Jeffersonians in Opposition."

37."A final aspect of these essays is worth remark, since it represents a strain in Republican thought which we encounter again and again: it is the effort to reduce the issue between the two sides to a dispute over the merits of republican government. Today this seems a false question; the issues of funding, assumption, the bank, taxation, and foreign policy seem real and substantial enough without superimposing on them an artificial quarrel over a question of monarchy and hereditary power which all but the tiniest handful of Americans agreed. But the exaggerated passions of both sides can be understood if we remember that most politically conscious Americans were acutely aware of being involved in a political experiment in republicanism that was attended by difficulties of the most acute kind and that might face many hidden and unpredictable pitfalls. Both sides were nervous about the stability of republicanism in an extensive federal union pervaded by many differences of sensibility and interest." Hofstadter, 1968, p.p. 84-5. In this passage Hofstadter articulates the notion than any movement away from the perfect balance is a move down a slippery slope "back towards monarchy and the hereditary principle." My only qualification to Hofstadter is his overemphasis on the fear of monarchy relative to the fears of systematic corruption represented by the funding system.

38.John Taylor, A Definition of Parties, (1794), p. 2; cited in Hofstadter, 1968, p. 100.

39.In particular see McCoy, 1980, chapter Three, "Commerce and the Independent Republic," pp. 76-104. The opening chapters to McCoy lay out the Whig origins of Republican thought as clearly as Banning, 1978. The essential role of corruption in McCoy's analysis is captured in the title to chapter One: "Social Progress and Decay in Eighteenth Century Thought."

40.Wallis and Weingast, 2004, investigate the causes of federal inaction.

41.The history of government promotion of transportation improvements, federal, state, and local, is Goodrich, 1960. Larson, 2001, supplements Goodrich's study of the politics of federal internal improvements. The history of banking is enormous. State banking is the subject of two recent books by Bodenhorn, 2000 and 2003.

42.In the decade of the 1800s, New York averaged 18 incorporations per year, Ohio 1, Maryland 2, Pennsylvania 6, and New Jersey 4. In the 1830s, New York averaged 57, Ohio 43, Maryland 18, Pennsylvania 38, and New Jersey 18; Evans, 1948. There is a substantial historical and legal literature on American corporations: Davis, 1961, Dodd, 1954, Hurst,1970, Handlin and Handlin,1969, Seavoy, 1982, Maier, 1992 and 1993, Lamoreaux, 2004, and Dunlavy, 2004.

43.For state involvement in banking in the early $19^{\text {th }}$ century see Wallis, Sylla, and Legler, 1994; Sylla, Legler, and Wallis, 1987; and Bodenhorn, 2000 and 2003. 
44.Larson, 2001, p. 119.

45.Maier (1992), pp. 73-4.

46.See Handlin and Handlin, 1969, for a clear statement of how corporation policy in Massachusetts was used to support private organizations.

47.See Bodenhorn, this volume, Seavoy, 1982, and Benson, 1961, for the political uses of bank chartering in New York.

48.Wallis, Sylla, and Legler (1994) present a simple model of "fiscal interest" that explains why some states chose to limit entry into banking in return for higher dividends on the bank stock they owned. Pennsylvania consciously limited entry into banking. New Jersey created a monopoly railroad, the Camden and Amboy, from which the state received substantial dividends (Cadman, 1949). In Arkansas, two politically powerful families used a state bank for the same purposes as the Albany Regency; Worley (1949 and 1950).

49.Eaton, 1824, p. p. 3-4, as quoted in Larson, 2001, p. 154. The quote is from Letters of Wyoming, campaign pamphlets that began appearing in 1823, written by John Eaton, later Jackson's Secretary of War. "Eaton was constructing for Jackson our of older republican cloth a coat of virtue and simplicity that made other candidates appear to be draped in ancient, Britishstyle corruption.” Larson, 2001, p. 155.

50.Jackson to Lewis, February 20, 1825; as quoted in Remini, 1981, p. 98.

51.See Remini, 1967, and Temin, 1969. The debate in economic history over the effects of the Bank War, Jackson's other economic policies, and the causes of the macroeconomic rages on. For a summary of the literature, and a strong argument that Jackson's domestic economic policies contributed to the Panic of 1837, see Rousseau, 2003.

52. "It is to be regretted that the rich and powerful too often bend the acts of government to their selfish purposes. Distinctions in society will always exist under every just government.... but when the laws undertake to add to these natural and just advantages artificial distinctions, to grant titles, gratuities, and exclusive privileges, to make the rich richer and the potent more powerful, the humble members of society - the farmers, mechanics, and laborers - who have neither the time nor the means of securing like favors to themselves, have a right to complain of the injustice of their government. There are no necessary evils in government. Its evils exist only in its abuses.

If we can not at once, in justice to interest vested under improvident legislation, make our government what it ought to be, we can at least take a stand against all new grants of monopolies exclusive privileges, against any prostitution of our Government to the advancement of the few at the expense of the many, and in favor of compromise and gradual reform in our code of laws and system of political economy." Jackson's Veto Message, July 10, 1832, Richardson, 1897, pp. 1153-4. 
53.From "Paper read to the Cabinet" in the Jackson Papers, L.C.; as quoted in Remini, 1967, Bank War, p. 119.

54.Henry Clay's speech on the "Removal of Deposits," December 30, 1833. Register of Debates, $21^{\text {st }}$ Congress, $1^{\text {st }}$ Session, p. 94.

55.Sprague colorfully expanded on the dangers of Jackson. "The people love their constitution, their liberties, and themselves. They are always politically honest.... But they are not infallible... oftentimes a military chieftain, having wrought real or fancied deliverance by successful battles -- fervent gratitude, unbounded admiration, the best feelings of our nature, rush towards him... In the paroxysm of their devotion, they are ready at his shrine to sacrifice their rights, their liberties, their children, and themselves." Senate Debate, 23rd Congress, 1st Session, on the Removal of the Deposits, Register of Debates, pp. 386-87. January 29, 1834.

56.Hoftstader's, 1968, is particularly illuminating on the rise of parties and the role played by Martin Van Buren in the process of rationalizing the need for parties in a democracy.

57.See Wallis, Sylla, and Grinath, 2004, for a description of the default crisis and a discussion of its causes. We explicitly consider the role played by naivete and corruption and find that most states were neither.

58.By the 1830 s most of the original states had experience with two or more state constitutional conventions and the state ratifying conventions for the national constitution. Only North Carolina and Massachusetts, stayed with their first constitution through the Civil War. By 1860, states had written the following number of constitutions: Connecticut, 2; Delaware, 3; Georgia, 3; Maryland, 2; New Hampshire, 3; New Jersey, 2; New York, 3; Pennsylvania, 3; South Carolina, 3; Vermont, 2; Virginia, 3. Of the new states: Kentucky, 2; Tennessee, 2; Maine was part of Massachusetts until 1820 when it wrote a new constitution. In addition to the new constitutions, there were several constitutional conventions that produced constitutions that were not ratified by the voters.

59.Andrew Jackson's first complaint in his veto of the proposed charter renewal for the Second Bank of the United States was that the government wasn't getting a good enough deal: "Every monopoly and all exclusive privileges are granted at the expense of the public, which ought to receive a fair equivalent... If our Government must sell monopolies, it would seem to be its duty to take nothing less that their full value, and if gratuities must be made once in fifteen of twenty years let them not be bestowed on the subjects of a foreign government nor upon a designated and favored class of men in our own country." Veto Message, July 10, 1833, Richardson, 1897, pp. 1140-1141.

60.The history of these constitutional changes in presented in Wallis, 2005. The general relationship between public finance and corporations is discussed in Wallis, 2003. For a history of incorporation laws see Evans, 1948, for and a larger discussion of the $19^{\text {th }}$ century corporation see Hurst, 1970. 
61.See Wallis, Fishback, and Kantor, this volume, for a discussion of social welfare in the New Deal and the end of corruption in relief administration.

62.For a comparison on corporate chartering in France and the United States, see Lamoreaux and Rosenthal, 2004. Their point that the options open to structure firms in France was much more flexible than the options open to firms in the United States is a key argument in the following section.

63.For a discussion of general acts see Dunlavy, 2004; Million, 1990; and Mark, 2000. The actual structure of corporations under general acts is an area of which legal and economic historians are almost completely ignorant. Dunlavy's paper and her current project examining a large sample of corporate charters, is beginning to shed light on this critical area.

64.For the history of New Jersey corporations, see Cadman, 1949. For the specifics of New Jersey’s changing corporation policy, see Grandy, 1989.

65."By the end of the merger wave, revenue from incorporation fees and franchise taxes represented more than 60 percent of State Fund revenues. The state budget moved solidly into the black by 1890 and stayed there into the next century. By 1902 New Jersey had eliminated its bonded debt and had abolished its state property tax." Grandy, 1989, pp. 681-3.

66. "New Jersey charters represented more than 60 percent of firm disappearances and almost 80 percent of the capitalization of these combinations. Half of John Moody's 318 "industrial trusts" bore New Jersey charters - including all of his seven "greater industrial trusts." Grandy, 1989, p. 678. See Lamoreaux, 1985, and Nelson, 1959, for more detailed history of the merger movement.

67.This "trust" is historically relative; Americans retain a profound ability to mistrust government. 


\section{References}

Aristotle. 1996. The Politics and the Constitution of Athens. Edited by Stephen Everson, New York: Cambridge University Press.

Bailyn, Bernard. The Ideological Origins of the American Revolution. Cambridge: Harvard University Press, 1967.

Banning, Lance. The Jeffersonian Persuasion. (Ithaca: Cornell University Press, 1978).

Benson, Lee. The Concept of Jacksonian Democracy: New York as a Test Case. (Princeton: Princeton University Press, 1961).

Bodenhorn, Howard. A History of Banking in Antebellum America. (Cambridge: Cambridge University Press, 2000).

Bodenhorn, Howard. State Banking in Early America: A New Economic History. (Oxford: Oxford University Press, 2003).

Bolingbroke. 1997. Political Writings. Edited by David Armitrage, New York: Cambridge University Press.

Brewer, John. 1989. The Sinews of Power: War, Money, and the English State, 1688-1783. New York: Knopf.

Cadman, John W. The Corporation in New Jersey: Business and Politics, 1791-1875. (Cambridge; Harvard University Press, 1949).

Callender, Guy Stevens. "The Early Transportation and Banking Enterprises of the States." Quarterly Journal of Economics , vol. XVII, no. 1 (November,1902), 111-162.

Clague, Christopher. "The International Campaign against Corruption: An Institutionalist Perspective," in Heckelman and Coates, ed. Collective Choice: Essays in Honor of Mancur Olson, (New York: Springer, 2003).

Davis, John P. 1961. Corporations: A Study of the Development of the Origin and Development of Great Business Combinations and their Relation to the Authority of the State. New York: Capricorn.

De Toqueville, Alexis. 1966. Democracy in America. Translated by George Lawrence, New York: Harper and Row.

DeWitt, Benjamin Parke.1915. The Progressive Movement: A Non-partisan, Comprehensive Discussion of Current Tendencies in American Politics. Reprinted by The University of 
Washington Press, Seattle, 1968

Dickson, P.G.M.. 1967. The Financial Revolution in England. London: Macmillan, St. Martin's Press.

Dodd, Edwin Merrick, 1954. American Business Corporations until 1860; with Special Reference to Massachusetts. Cambridge; Harvard University Press.

Dunlavy, Colleen A. "From Citizens to Plutocrats: Nineteenth Century Shareholder Voting Rights and Theories of the Corporation," in Crossing Corporate Boundaries: History, Politics, and Culture, in Kenneth Lipartito and David B. Sicilia, eds. (New York: Oxford University Press, 2004).

Evans, George Heberton. Business Incorporations in the United States, 1800-1943. (NBER, Baltimore: Waverly Press, 1948).

Ferguson, E. James. 1961. The Power of the Purse: A History of American Public Finance, 1776-1790. Chapel Hill: University of North Carolina Press.

Ferejohn, John, Jack N. Rakove, and Jonathan Riley. 2001. Constitutional Culture and Democratic Rule. New York: Cambridge University Press.

Fishback, Price V. and Shawn Everett Kantor. 2000. A Prelude to the Welfare State: The Origins of Worker Compensation. Chicago: University of Chicago Press.

Goodrich, Carter. Government Promotion of American Canals and Railroads. (New York: Columbia University Press, 1960).

Goodrich, Carter, "The Revulsion Against Internal Improvements." Journal of Economic History, X, (November 1950),145-169.

Grandy, Chrisopher. 1989. "New Jersey Corporate Chartermongering, 1875-1929." Journal of Economic History, 49 (September), 677-692.

Handlin, Oscar and Mart Flug Handlin. 1969. Commonwealth: A Study of the Role of Government in the American Economy: Massachusetts, 1774-1861. Cambridge: Belknap Press, 1969.

Harrington, James. 1992. The Commonwealth of Oceana and A System of Politics. Edited by J.G.A. Pocock. New Yorlk: Cambridge University Press.

Hofstadter, Richard. The Idea of a Party System. Berkeley: University of California Press, 1969. 
Hurst, James Willard, 1970. The Legitimacy of the Business Corporation in the Law of the United States, 1780-1970. Charlottesville: University of Virginia Press.

Jensen, Merrill. 1940. The Articles of Confederation. Reprinted 1970. Madison: University of Wisconsin Press.

Klitgaard, R. Controlling Corruption. (Berkeley: University of California Press, 1988).

Kruman, Marc W. Between Authority and Liberty: State Constitution Making in Revolutionary America. (Chapel Hill: University of North Carolina Press, 1997).

Lamoreaux, Naomi. "Parnerships, Corporations, and the Limits on Contractual Freedom in U.S. History: An Essay in Economics, Law, and Culture," in Crossing Corporate Boundaries: History, Politics, and Culture, in Kenneth Lipartito and David B. Sicilia, eds. (New York: Oxford University Press, 2004).

-----. 1985. The Great Merger Movement in American Business, 1895-1904. New York: Cambridge University Press.

Lamoreaux, Naomi and Jean-Laurent Rosenthal, "Legal Regime and Business's Organizational Choice.” NBER Working paper 10288, February, 2004.

Larson, John Lauritz. 2001. Internal Improvement: National Public Works and the Promise of Popular Government in the Early United States. (Chapel Hill: University of North Carolina Press).

Machiavelli, Niccolo. 1996. Discourses on Livy. Translated by Mansfield and Tarcov. Chicago: University of Chicago Press.

Maier, Pauline, 1993 "The Revolutionary Origins of the American Corporation." William and Mary Quarterly, 3d series, 50, 1 (January 1993), 51-84.

Maier, Pauline, "The Debate Over Incorporations: Massachusetts in the Early Republic," in Conrad Wright, ed. Massachusetts an the New Nation. (Boston: Massachusetts Historical Society, 1992).

Malone, Laurence J. Opening the West: Federal Internal Improvements Before 1860. (Westport, CT: Greenwood Press, 1998).

Mathias, Peter and Patrick O’Brien, 1976. ""Taxation in Britain and France, 1715-1810: A Comparison of the Social and Economic Incidence of Taxes collected for the Central Government." Journal of European Economic History.

McCormack, Richard L.1981. "The Discovery the Business Corrupts Politics." The American 
Historical Review, 86 (April), 247-274.

McCoy, Drew R. 1980. Elusive Republic: Political Economy in Jeffersonian America. Chapel Hill: University of North Carolina Press.

McKee, Samuel Jr., ed. 1934. Alexander Hamilton's Papers on Public Credit Commerce and Finance. New York: Columbia University Press.

Million, David. 1990. "Theories of the Corporation.” Duke Law Journal, 201-262.

Murrin, John M. "Escaping Perfidious Albion: Federalism, Fear of Corruption, and Democratization of Corruption in Postrevolutionary America." in Richard K. Matthews, ed., Virtue, Corruption, and Self-Interest. Bethlehem: Lehigh University Press, 1994.

Namier, Sir Lewis and John Brooke, 1964. The House of Commons, 1754-1790. London: Parliament Trust.

Nelson, Ralph L. 1959. Merger Movements in American Industry, 1895-1956. Princeton: Princeton University Press.

North, Douglass C. and Barry R. Weingast. 1989. "Constitutions and Commitment: The Evolution of Institutions Governing Public Choice in Seventeenth Century England." Journal of Economic History, 49 (December), 189-210.

Pocok, J.G.A. Virtue, Commerce, and History. Cambridge: Cambridge University Press, 1985.

----- 1977. ed. The Political Works of James Harrington. Cambridge: Cambridge University Press.

----- 1975. The Machiavellian Moment: Florentine Political Thought and the Atlantic Republican Tradition. Princeton: Princeton University Press.

----. 1973. Politics, Language, and Time. New York: Atheneum.

----. 1987. Ancient Constitution and the Feudal Law. New York: Cambridge University Press.

Pocock, J.G.A. "Virtue and Commerce in the Eighteenth Century." Journal of Interdisciplinary History 3 (72) p 124-5.

Polybius.1962. The Histories of Polybius, vol. 1. Translated from the text of F. Hultsch by Evelyn S. Shuckburgh. Westport, CT: Greenwood Press.

Richardson, James D. 1897. The Messages and Papers of the Presidents. Washington: Bureau of National Literature. 
Remini, Robert V. 1967. Andrew Jackson and the Bank War. New York: W.W. Norton.

Robbins, Caroline. 1959. The Eighteenth-Century Commonwealthman. Cambridge: Harvard University Press.

Rose-Ackerman, Susan. Corruption: A Study in Political Economy, (New York: Academic Press, 1978).

Rousseau, Peter. 2002. "Jacksonian Monetary Policy, Specie Flows, and the Panic of 1837." Journal of Economic History, 62 (June), 457-488.

Seavoy, Ronald E. The Origins of the American Business Corporation, 1784-1855. (Westport: Greenwood Press, 1982).

Shalhope, Robert E. 1972. "Toward a Republican Synthesis: The Emergence of an Understanding on Republicanism in American Historiography." The William and Mary Quarterly, 29 (January), 49-80.

-----. 1982. "Republicanism and Early American Historiography." The William and Mary Quarterly, 39 (April), 334-356.

Shleifer and Vishny, "Corruption." Quarterly Journal of Economics, 108, 3, (1993), 599-617.

Smith, Adam. 1776. The Wealth of Nations.

Sylla, Richard, John B. Legler, and John Joseph Wallis. "Banks and State Public Finance in the New Republic." Journal of Economic History, 47, 2 (June, 1987.), 391-403.

Temin, Peter. 1969. The Jacksonian Economy. New York: W. W. Norton and Company.

Trenchard, John and Thomas Gordon. 1995. Cato's Letters. Edited by Ronald Hamowry. Indianapolis: Liberty Fund.

Wallis, John Joseph, Arthur Grinath, and Richard Sylla, "Debt, Default, and Revenue Structure." NBER Working Paper and mimeo, 2004.

Wallis, John Joseph, Richard Sylla and John Legler. "The Interaction of Taxation and Regulation in Nineteenth Century Banking." In Goldin and Libecap, eds. The Regulated Economy: A Historical Approach to Political Economy, (Chicago: University of Chicago Press, 1994, pp. 121-144).

Wallis, John Joseph, 2000, “American Government Finance in the Long Run: 1790 to 1990," Journal of Economic Perspectives, 14, 1, (January, 2000), 61-82 . 
----. 2001. "History of the Property Tax," in Property Taxation and Local Government Finance, Wallace E. Oates, ed., (Cambridge: Lincoln Institute, 2001), 123, 147.

----- 2003. "Market Augmenting Government? The State and the Corporation in 19th Century America" in Omar Azfar and Charles Cadwell, ed. Market-Augmenting Government: The Institutional Foundations for Prosperity. (Ann Arbor: University of Michigan Press, 2003).

-----. 2003A. "The Property Tax as a Coordination Device: Financing Indiana's Mammoth System of Internal Improvements." Explorations in Economic History. (July 2003).

-----. 2003B. "The Public Promotion of Private Interest (Groups)" Collective Choice: Essays in Honor of Mancur Olson, Jac Heckelman and Dennis Coates, ed. Springer-Verlag.

----. 2004. "American Government and the Promotion of Economic Development In the National Era, 1790 to 1860," forthcoming in Fishback, ed.

----- 2005. "Constitutions, Corporations, and Corruption: American States and Constitutional Change, 1842 to 1852." NBER Working Paper \#10451. Forthcoming in the Journal of Economic History.

-----. The NBER/Maryland State Constitution Project, http://129.2.168.174/constitution/.

Wallis, John Joseph and Barry Weingast. 2004. "Equilibrium Federal Impotence: Why the States and Not the American National Government Financed Infrastructure Investment in the Antebellum Era." Mimeo.

Weston, Corinne Comstock. 1965. English Constitutional Theory and the House of Lords, 15561832. London: Routledge \& Kegan Paul.

Wood, Gordon S. 1969. The Creation of the American Republic, 1776-1787. Chapel Hill: University of North Carolina Press.

Worley, Ted R. "The Control of the Real Estate Bank of the State of Arkansas, 1836-1855." The Mississippi Valley Historical Review, 37, 3 (December 1950), 403-426. 